\title{
Functional Disaster Resistant Buildings
}

\author{
Authors \\ Young, William \\ Haggard, James \\ Presented at: \\ Institute of Electrical and Electronic Engineers \\ $4^{\text {th }}$ World Conference on Photovoltaic Energy Conversion \\ Waikoloa, Hawaii, USA \\ May 7-12, 2006
}

Publication Number

FSEC- PF-389-06

Copyright

Copyright (c) Florida Solar Energy Center/University of Central Florida

1679 Clearlake Road, Cocoa, Florida 32922, USA

(321) 638-1000

All rights reserved.

\section{Disclaimer}

The Florida Solar Energy Center/University of Central Florida nor any agency thereof, nor any of their employees, makes any warranty, express or implied, or assumes any legal liability or responsibility for the accuracy, completeness, or usefulness of any information, apparatus, product, or process disclosed, or represents that its use would not infringe privately owned rights. Reference herein to any specific commercial product, process, or service by trade name, trademark, manufacturer, or otherwise does not necessarily constitute or imply its endorsement, recommendation, or favoring by the Florida Solar Energy Center/University of Central Florida or any agency thereof. The views and opinions of authors expressed herein do not necessarily state or reflect those of the Florida Solar Energy Center/University of Central Florida or any agency thereof.

\section{A Research Institute of the University of Central Florida}




\author{
Institute of Electrical and Electronic Engineers \\ $4^{\text {th }}$ World Conference on Photovoltaic Energy Conversion \\ Waikoloa, Hawaii, USA \\ May 7-12, 2006
}

FUNCTIONAL DISASTER RESISTANT BUILDINGS

\author{
William R. Young, Jr., Senior Research Engineer \\ James Haggard, Engineering Assistant \\ Florida Solar Energy Center, Cocoa, Florida 32922
}

\begin{abstract}
Natural disasters, such as hurricanes, floods, tornados, tsunami and earthquakes, are becoming a greater problem as they destroy lives, homes, businesses and the natural environment. Such disasters can happen with little or no warning, leaving hundreds or even thousands of people without medical services, potable water, sanitation, communications and electrical services for up to several weeks. One proactive strategy to minimize this type of destruction and disruption to lives is the implementation of disasterresistant buildings that are energy efficient, fortified to the latest codes, and incorporate renewable energy systems. This approach uses the best energy-efficient buildings, fortified to the latest codes, and incorporates renewable energy systems.
\end{abstract}

\section{INTRODUCTION}

There isn't a citizen of the United States let alone the world, that isn't thinking about the result of unexpected disasters. The reality is that we will face more of these types of challenges and must prepare for them. First, we must study these disasters, not just mourn them. Whether natural or man-made, disruptions to power can impact our daily life in ways that are only felt when the disaster hits. In order to create an environment where solutions to mitigate these changes can be created, we must first understand where the destruction comes from and how it impacts us.

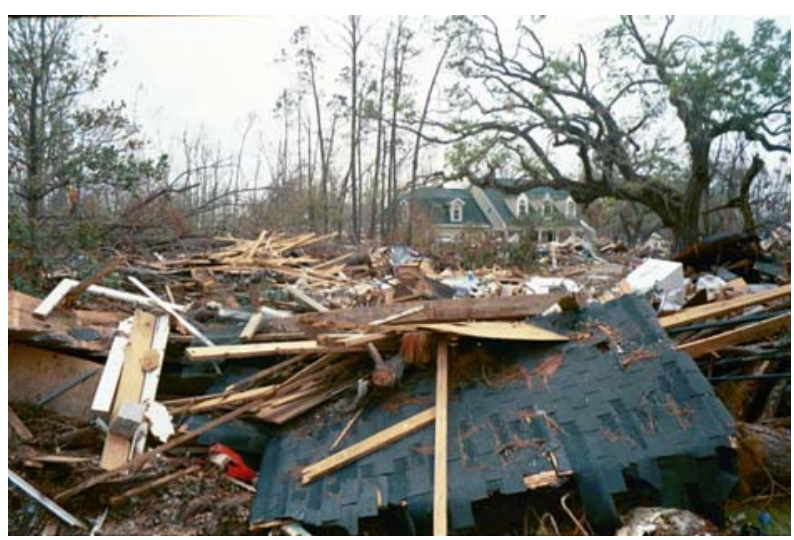

Fig. 1. Picture of destroyed house in Bay St. Louis, Mississippi after Hurricane Katrina.
There are a variety of disruptive sources, such as hurricanes and terrorist acts, that can cause disruptions in power and energy delivery systems. Recent events have shown us how vulnerable we are to these disruptions, as well as how unexpected they can be. In order to better understand these disruptions and their impacts on the population, we will focus on two major events: the massive power outage experienced in northeastern part of the United States and Hurricane Katrina's impact on the Gulf Coast.

On August 14, 2003, over 40 million people in the U.S. and about 10 million people in Canada experienced a sudden, unexpected loss of electrical power. This outage, first thought to be a terrorist action, later turned out to be caused by a number of weaknesses in the management of the power grid and the communication protocols between power generation/transmission companies. This outage resulted in the loss of water pressure to over four million customers in Detroit alone; these customers were under a boil water advisory for four days. In addition to the loss of water services, all trains running into and out of New York City were shut down. Even though most communications systems were available due to backup power systems, both wireline and wireless systems were overwhelmed and many people were unable to make calls or gather additional information about the situation. The bottom line is that loosing large portions of the electrical grid can affect us in ways that we don't expect-- from basic sanitation services to transportation and communications.

The citizens of Alabama, Louisiana, and Mississippi are still feeling hurricane Katrina's aftermath. Katrina was the 11th named storm of the 2005 season and one of the deadliest hurricanes in American history. Over three million people were without electricity after the storm passed; only about a third of the damaged structures had power restored some six months later. The damage to the utilities extended beyond power grid issues to natural gas delivery systems and other services used by residents. Hurricane Katrina poses a unique kind of threat to mitigate. The damage caused by the hurricane was not just from wind and debris but also massive flooding. This paper will discuss ways to mitigate losses from power outages which could have been helpful to the citizens of the three most heavily 
damaged states. In the cases where the structures were completely destroyed, however, no building code or technological improvements can maintain a level of comfort for inhabitants during or shortly after the storm.

\section{SOLUTIONS}

The impact that disruptions from a disaster bring can be easily understood. Using the real-life disasters described above, one must simply imagine a situation where all services (including utilities, deliveries, and communications) are cut off. There are ways to reduce the disruption and inconvenience caused by the loss of these services. The solution to creating a safe, functional, and somewhat comfortable environment after a disaster is to combine building improvements with renewable energy sources.

\section{Disaster-resistant buildings}

In the late 1990's, the Federal Emergency Management Agency (FEMA) began a new approach to mitigation by promoting disaster-resistant buildings for disasterresistant communities. A disaster-resistant building is built beyond conventional building methods and codes. This building method will likely cost more at the time of construction, but is positioned to deliver priceless life and property saving during and after a disaster. As an example, a disaster-resistant building might have foundation to roof connections, water barriers along the roof joints and wildfire buffers around the perimeter. The Federal Alliance for Safe Homes created the Blueprint for Safety program to provide a comprehensive set of disaster-resistant building techniques for protecting both new and existing homes from hurricanes, tornadoes, flooding, and wildfires. The Institute for Business and Home Safety created the Fortified Builder's Guide to provide techniques for a higher level of protection against disasters. These and other programs are available to provide guidance to structurally enhance a building to save life and reduce property damage. Preparedness and mitigation to reduce damage and losses reduces the amount of response and recovery effort potentially needed.

Following a disaster, if the building is still standing, the building design should provide sustainable operational use. The U.S. Department of Energy, with support from the Florida Solar Energy Center (FSEC), added the concept of building functionality and operational capacity to the importance of creating structurally sound and safe buildings. A disaster-resistant building should achieve the lowest energy consumption, applying a variety of possible energy efficiency and conservation options. Energy consumption can be minimized to various degrees, with the ultimate being zero energy input from the conventional grid utilities. Energy codes are needed to promote sustainability; this represents a step beyond minimum energy codes. From an energy security aspect, zero energy buildings would have energy production in close proximity to the load and would provide energy generation equal to consumption.

Public schools are the primary source of public shelter during emergencies, currently accounting for about 93 percent of statewide hurricane shelter space. The Florida State Legislature established statues defining state, county government and school districts' responsibility for safety of life and property during a declared emergency. International, national, and local building codes were enacted to ensure safe buildings, thereby reducing deaths, injuries and property damage.

A new approach in shelter management for people with disabilities and special health needs is to make their homes and care facilities disaster-resistant and energy secure. Ideally, homeowners and care centers should consider the advantages of creating disaster-resistant houses and facilities with renewable energy resources. The concept is to structurally fortify their homes and living facilities and provide fail-safe energy resources to power their needs. The purpose is to maintain the operation of their habitats so as not to impact their lives and burden public shelter programs.

\section{Renewable Energy Sources}

Once a strong reliable structure is in place, renewable power sources that don't depend on utility power are needed to help raise the level of comfort and keep critical medical and business equipment going. Renewable resources, such as photovoltaic, biomass, geothermal, small hydro, solar thermal, and wind have attractive security attributes and reduce the risk of pipeline interruptions and central station outages. They are an environmentally benign and inexhaustible source of energy.

The Florida Solar Energy Center, Sandia National Laboratories, and the National Renewable Energy Laboratory have jointly researched the application of PV in disasters. It has been determined that PV plays an important role in response, recovery and mitigation in disasters. The longer power is out, the greater the benefit of $\mathrm{PV}$ as a sustainable power source. There are many appropriate applications for PV - for years, it has powered monitoring systems for information and safety; now, PV-powered surveillance systems promote energy security in the battle against terrorism. Small utilityinteractive PV systems with battery backup increase the effectiveness of disaster-resistant buildings and ultimately support communities in the power mix for distributed generation.

PV equipment requires no fuel, so the length of operation poses no problem when the solar power system is properly designed. Solar energy is a viable, cost effective resource for small portable and stand- 
alone electrical power applications since it offers lower operating costs than gasoline generators. PV arrays are modular, allowing various outputs and the addition of battery storage to a PV system providing 24-hour, 7 days a week operation. Commercial PV modules must meet durability and reliability standards for high winds, hail, electrical characteristics, and other factors. The array and system should be designed to meet similar standards and codes.

PV-powered systems are a natural solution because they can be designed specifically for stand-alone operation without utility power. PV can power the whole building or part, as well as powering critical items. Some uses, like communications and applications in medical clinics, require quiet, non-polluting operation, which PV is capable of providing. A viable use for PV is to meet the emergency demands in large-scale disasters, where power will be out for long periods of time and where survivor support is difficult to provide due to the extensive area destroyed.

There are also inappropriate applications for PV in response to disasters. The large-scale power needs of sewer and water facilities, hospitals, large shelters, and emergency operations centers are better met by gasoline or diesel generators in an emergency. Locations or equipment requiring hundreds of kilowatts of emergency power would require large areas of open space and cost hundreds of thousands of dollars for PV arrays.

Emergency management, business owners, and homeowners need to understand their energy needs and photovoltaic technology to make the right application choice.

\section{Power Design Considerations}

Energy analysis of various homeowners' needs suggest that a minimum of a $1 \mathrm{~kW}$ photovoltaic array with a $2 \mathrm{~kW}$ inverter and battery storage would continuously power most critical needs. The building may have $1 \mathrm{~kW}$ to $20 \mathrm{~kW}$ or more of $\mathrm{PV}$ based on design criteria and electrical applications. The PV system can be ground or roof mounted, depending on building design and orientation. The system may be utility interactive with battery back up to power critical items during power outages. During normal times, the PV system would provide demand side management, offsetting energy consumption. During outages, the system would power critical items required to survive.

Both homeowners and businesses will benefit from evaluating their energy needs and operational activities. The more energy conserved, the less energy that needs to be produced. The level of need for electricity determines the level of application of PV and its connection to other electrical sources. Past research has shown that PV energy can be applied at five functional design levels, as shown in the table below.

Table 1. PV Levels.

\begin{tabular}{|c|c|l|l|}
\hline Level & Item & Description & PV Power \\
\hline 1 & $\begin{array}{c}\text { Selected } \\
\text { items }\end{array}$ & $\begin{array}{l}\text { Outdoor lights, pump, } \\
\text { gate control }\end{array}$ & $\begin{array}{l}0-200 \\
\mathrm{~W}\end{array}$ \\
\hline 2 & $\begin{array}{c}\text { Critical } \\
\text { items }\end{array}$ & $\begin{array}{l}\text { Refrigerator, lights, } \\
\text { radio, register }\end{array}$ & $\begin{array}{l}\text { 200-1000 } \\
\mathrm{W}\end{array}$ \\
\hline 3 & $\begin{array}{c}\text { Backup } \\
\text { power }\end{array}$ & $\begin{array}{l}\text { Lighting, kitchen, } \\
\text { water supply, systems }\end{array}$ & $\begin{array}{l}500-2000 \\
\mathrm{~W}\end{array}$ \\
\hline 4 & $\begin{array}{c}\text { Zero } \\
\text { energy }\end{array}$ & $\begin{array}{l}\text { Production equals } \\
\text { consumption }\end{array}$ & $\begin{array}{l}2000-20+ \\
\mathrm{kW}\end{array}$ \\
\hline 5 & Producer & $\begin{array}{l}\text { Net generator beyond } \\
\text { consumption }\end{array}$ & $\begin{array}{l}10-100+ \\
\mathrm{kW}\end{array}$ \\
\hline
\end{tabular}

The first level of PV generation is a dedicated standalone device with a consistent load. They are usually single purpose devices, such as, a solar outdoor light, weather station, monitoring equipment, instrumentation equipment, security systems and consumer type devices. The second level is targeted to power critical energy needs in the home or commercial building to ensure needed power is available to maintain key operations. The third level of generation may be to power the garage, kitchen, business computer systems, water supply or other major systems, to generate as much power as your can afford, but not everything. Another consideration for this level is storage for standalone operation when utility power is out. This is usually supplied by batteries with a minimal storage capacity of $1 \mathrm{~kW} / \mathrm{hr}$. The fourth level is to power the whole building and produce as much as is consumed. The fifth level is designed to become a power generator for the purpose of redistribution and produces a set amount more than is consumed.

Paying special attention to levels 2 through 4 would be advantageous in disaster-resistant building design. Levels 2 and 4 use backup power systems that may be stand-alone or grid interactive. They can be configured to power small electrical and electronic devices or small systems. Of most interest to business owners and emergency managers is the critical power supply concept where critical energy needs are identified and incorporated into a power supply design to ensure power is available to maintain key operations and functions of a building. As an example, during a power outage, a homeowner will want to have electricity for operating a lamp, a refrigerator, and a radio. A business may need a few lights for safety and a cash register to complete sales. Most consumers would consider these items critical to maintaining business operations, building functions and personal lifestyle until utility power is restored. By incorporating even minimal building modifications, such as the addition of a small 
$1 \mathrm{~kW}$ photovoltaic array, the home or business owner can enhance energy security and realize long-term financial and environmental benefits. The best defense against the impact of disasters on power supplies is the zero energy building, with energy storage for emergencies.

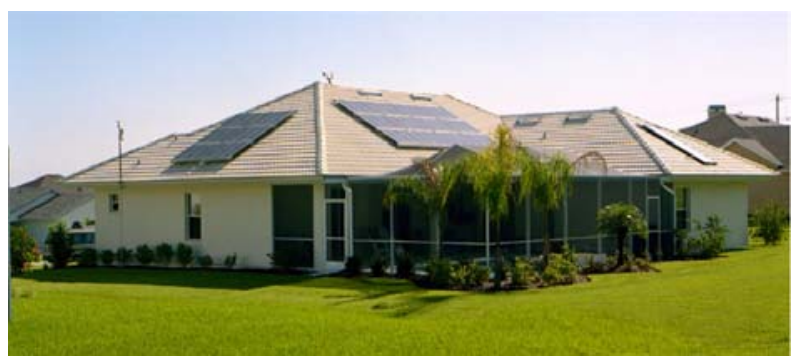

Fig. 2. Picture of a near zero-energy home in Lakeland, Florida.

\section{CONCLUSION}

As we have seen, disasters both natural and manmade, can be devastating. Though some damage and possibly catastrophic loss is not avoidable, the vast majority of homes and businesses affected can be preserved and made operational as soon as the disaster event has passed. The key to survivability of these structures is planning and close adherence to building codes.

Ideally, the truly disaster resistant building would be a zero energy home or building that ensures a high level of energy security. U.S. DOE Energy Star and Rebuild American programs provide many guidelines for energy efficiency and conservation measures. Conservation means not to do without, but to accomplish a similar or acceptable result using fewer resources. Once the load is minimized, renewable energy sources such as PV, thermal or wind, are applied to match energy needs. Distribute energy resources by applying the right energy source to the right application and employing multiple sources of energy.

If the building has been secured through careful design and construction, non-grid dependant utility services need to be restored. Using the lessons learned from the 2003 Northeast power outage, a careful inventory of devices that use utility power or services must be made. Once the inventory is complete, decisions about what devices must be powered and in what order of priority need to be made. A properly sized PV system along with solar thermal systems should be installed to maintain minimal continuous operation.
It is hoped that through the careful use of the recommendations outlined above, the disruptions caused by disasters will be greatly reduced; this will help in the recovery efforts after natural disasters.

\section{REFRENCES}

[1] Young, Jr, William, "Photovoltaic Applications for Disaster Relief", FSEC-CR-849-95, Florida Solar Energy Center, Cocoa, FL, USA, March. 2001.

[2] Phympton, Patricia, and Thornton, John, Solar Schools as Community Emergency Centers, Solar 2002, American Solar Energy Society, Reno, Nevada, June 2002.

[3] Hoff, T.E., C. Herig, and L. Gellettee, "Distributed PV's Contribution to American's Energy Security: Tax Revenue Protection for the Federal Government", Interim NREL Report, 2002

[4] Young, Jr. William, Ventre, Gerard, and Thomas, Micheal, "Needs Assessment for Applying Photovoltaics to Disaster Relief", FSEC-CR-935-97, Florida Solar Energy Center, FI, USA, July, 1997.

[5] Young, Jr. William, "History of Applying Photovoltaics to Disaster Relief", FSEC-CR-934-97, Florida Solar Energy Center, Cocoa, FI, USA, Jan 1997.

[6] Becker, William, R. Stauffer, "Rebuilding for the Future: A Guide to Sustainable Redevelopment for Disaster-Affected Communities", U.S. Department of Energy, September 1994

[7] Deering, Ann, John, Thornton, "Solar Solutions for Natural Disasters", Risk Management, February 2000

[8] Young, Jr. William, "Photovoltaics: Disaster and Energy Security Applications", World Renewable Energy Congress VIII, Denver, Colorado, FSEC-PF-373-03, Florida Solar Energy Center, August 2004

[5] Blueprint for Safety, Federal Alliance For Safe Homes, Tallahassee, Florida, 2002.

[6] Fortified Builders Guide, Institute For Business and Home Safety, Tampa, Florida, 2003. 